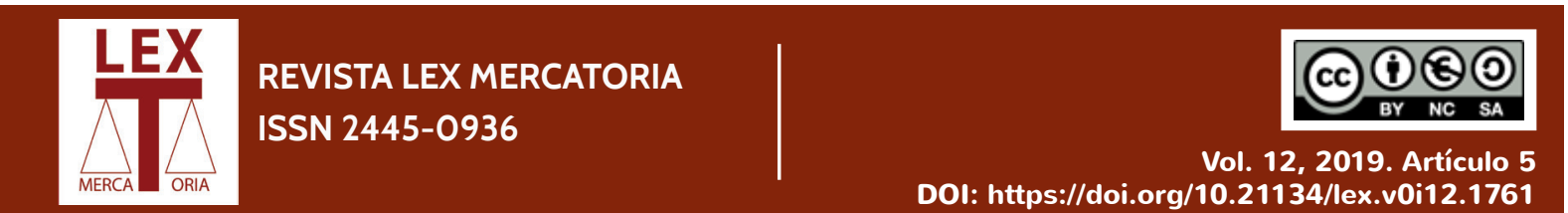

\title{
EXONERACIÓN DEL PASIVO INSATISFECHO Y SEGUNDA OPORTUNIDAD
}

\author{
José Luis Fortea Gorbe \\ Magistrado especialista en materia mercantil (CGPJ). \\ Doctor en Derecho (UA). Titular del Juzgado de lo mercantil $n^{\circ} 3$ de Alicante, con sede en Elche/
}

Elx.

Resumen

Recientes pronunciamientos de la Sala Primera del Tribunal Supremo han venido a facilitar la configuración del complejo régimen de exoneración del pasivo insatisfecho, especialmente en la delimitación del concepto de deudor de buena fe, la debida flexibilidad del procedimiento -exoneración provisional y definitiva- y el espinoso tema del crédito público y su inclusión en el plan de pagos, sin condicionantes desde la normativa de Derecho público.

\section{Palabras clave}

Concurso de persona física, deudor de buena fe, beneficio de exoneración del pasivo insatisfecho, procedimiento, y crédito público. 


\section{Introducción y marco legislativo nacional y europeo.}

\section{I.I Introducción al beneficio de exoneración del pasivo insatisfecho (BEPI).}

Para la comprensión de este instituto hay que partir de lo que dispone el art. 178.2 LC: en los casos de conclusión del concurso por liquidación o por insuficiencia de masa activa, el deudor persona natural quedará responsable del pago de los créditos restantes, y los acreedores podrán iniciar ejecuciones singulares, en tanto no se acuerde la reapertura del concurso o no se declare nuevo concurso; equiparándose para tales ejecuciones la inclusión de un crédito en la lista definitiva de acreedores a una sentencia de condena firme.

$Y$ frente a esa posibilidad se erige el beneficio de exoneración del pasivo insatisfecho en un concurso de acreedores del art. 178 bis LC, que supone una excepción legal al principio de responsabilidad patrimonial universal contenido en el art. 1911 Cc, pues se dirige a exonerar a los concursados del pasivo no satisfecho en el proceso concursal.

Al referido beneficio se accede exclusivamente por las personas físicas, empresarias o no - personas naturales, y de buena fe, según la dicción de la Ley concursal, arts. 178.2 LC en relación con el art. 178 bis. 1 LC- tras la conclusión del concurso por liquidación o por insuficiencia de masa; y viene a contrarrestar el principio de que el deudor sigue respondiendo de las deudas no pagadas en el proceso concursal, pudiendo los acreedo- res iniciar ejecuciones singulares, en tanto no se acuerde la reapertura del concurso o no se declare nuevo concurso.

El beneficio de exoneración del pasivo no satisfecho no limita sus efectos a los acreedores personados en el concurso; para facilitar al deudor una verdadera segunda oportunidad -" second chance"- se impide legalmente a los fiadores el ejercitar las acciones de regreso frente al deudor afianzado (art.178 bis 5 LC, párrafo tercero), salvo revocación del beneficio; y despliega sus efectos igualmente en relación a la economía y patrimonio familiar, incluyendo en su ámbito protector al cónyuge casado en régimen de gananciales o de comunidad, que no se hubiere extinguido durante el concurso, y respecto a las deudas anteriores al concurso de las que respondiera el patrimonio común (art.178 bis 5 LC, párrafo cuarto).

Como refirió GUTIÉRREZ DE CABIEDES ${ }^{1}$, la exoneración del pasivo insatisfecho, o, en terminología anglosajona, el "discharge», consiste en la exoneración al deudor de la obligación de pago de las deudas pendientes tras la conclusión del concurso -o del procedimiento específico que se establezca de solución de su situación de sobreendeudamiento o insolvencia- o tras de un periodo de tiempo determinado desde aquella conclusión, si se dan determinados presupuestos y se cumplen determinados requisitos. Es decir, con independencia de que la consientan o no los acreedores, pues la liberación de deudas tiene su fundamento en la Ley, tratándose de un objetivo de política legislativa en materia económica.

Así lo entendió el Tribunal Europeo de Derechos Humanos de Estrasburgo en la Sentencia de 20 de Julio de 2004, asunto

\footnotetext{
${ }^{1}$ GUTIÉRREZ DE CABIEDES, P. «La Liberación de la deuda restante tras la liquidación en el sobreendeudamiento de los particulares", en la obra colectiva dirigida por PULGAR EZQUERRA, J./PACCHI,S. El sobreendeudamiento de los particulares y del consumidor. Sistemas jurídicos europeos a debate. Ed. Euriconv., Lecce, Italia, 2014, pp.292.
} 
Bäck/Finlandia, en el que se concluyó que el "fresh start" o segunda oportunidad, no conculca el art. 1 del Protocolo $n^{\circ} 1$ del Convenio Europeo de Derechos Humanos de 4 de noviembre de 1950, por lo que el "discharge» no lesiona ningún derecho fundamental de los acreedores, y redunda en favor del interés público.

Ésta opinión es compartida por SENENT MARTÍNEZ/GALLEGO SÁNCHEZ/NIETO DELGADO/ VILLENA CORTÉS ${ }^{2}$, pues el art. 178 bis LC permite que el deudor quede liberado de sus obligaciones pendientes de pago tras la conclusión del concurso. Es decir, que el deudor ha de someterse a un mecanismo concursal para conseguir ese "discharge», superando los requisitos legales para la anhelada remisión definitiva de las deudas.

Ahora bien, esta solicitud únicamente la puede presentar el identificado en la LC como deudor de buena fe (art. 178 bis. 3 LC), planteando igualmente una configuración legal de este requisito, a modo de presupuesto para su concesión, aun con excepciones, como veremos.

Para la mejor comprensión de este beneficio de exoneración del pasivo insatisfecho en el concurso (en adelante, en su abreviatura BEPI), constataremos su breve evolución legislativa y su configuración desde la perspectiva comunitaria.

\section{I.II. Marco legislativo nacional.}

\section{I.II.I. Antecedentes.}

I antecedente más próximo se remonta a la Ley 14/2013, de 27 de septiembre, de Apoyo a los emprendedores y su internacionalización, en su artículo 21.5 modificó el apartado 2 del art. 178 $\mathrm{LC}^{3}$, introduciendo además de otras reformas de calado en la Ley Concursal, este instituto, pero limitado a las personas físicas empresarias, con una regulación muy simple, que posteriormente se vería corregida a través del RD-Legislativo 1/2015, de 27 de febrero.

\section{I.II.II. Regulación actual.}

El mecanismo de segunda oportunidad, se introduce definitivamente en nuestro ordenamiento, por vez primera para cualquier tipo de deudor persona natural -empresario y no empresario- y no solo para empresarios emprendedores, por el RD-Ley 1/2015, de 27 de febrero, y posterior Ley 25/2015, de 28 de julio, de mecanismo de segunda oportunidad, reducción de la carga financiera y

${ }^{2}$ SENENT MARTíNEZ, S.; GALLEGo SÁNCHEZ, A.M; NIETO DELGADO, C.; VILLENA CORTÉS, F.B.; «Real Decreto-Ley 1/2015, de 27 de febrero, de mecanismo de segunda oportunidad, reducción de carga financiera y otras medidas de orden social». Fascículo de actualización de la Ley Concursal Comentada, Ed. Francis Lefevre/El Derecho, Madrid 2015, p. 4.

${ }^{3}$ La redacción del art. 178.2 LC conferida por la Ley 14/2013 era la siguiente: "2. La resolución judicial que declare la conclusión del concurso del deudor persona natural por liquidación de la masa activa declarará la remisión de las deudas insatisfechas, siempre que el concurso no hubiera sido declarado culpable ni condenado por el delito previsto por el artículo 260 del Código Penal o por cualquier otro delito singularmente relacionado con el concurso y que hayan sido satisfechos en su integridad los créditos contra la masa, y los créditos concursales privilegiados y, al menos, el 25 por ciento del importe de los créditos concursales ordinarios. Si el deudor hubiere intentado sin éxito el acuerdo extrajudicial de pagos, podrá obtener la remisión de los créditos restantes si hubieran sido satisfechos los créditos contra la masa y todos los créditos concursales privilegiados." 
otras medidas del orden social, con el nuevo art. 178 bis LC. Un único artículo, el 178 bis LC, regula la concesión del beneficio de la exoneración del pasivo insatisfecho, denominado en adelante BEPI.

CUENA CASAS $^{4}$ valoró positivamente la reforma, especialmente por su ámbito subjetivo de aplicación, que ya contempla un ámbito de aplicación subjetivo que va más allá del empresario autónomo persona física, ampliándose al consumidor sobre endeudado, es decir, a toda persona natural, no empresario.

La doctrina ha sustentado los efectos totalmente favorables en relación al deudor, al acreedor y a la sociedad en general, que sintetiza magistralmente BATLLORI ${ }^{5}$, en la siguiente forma:

-Los beneficios para el deudor insolvente: se le incorpora de nuevo a la sociedad y a la actividad económica; puede abandonar la economía sumergida; se evita su estigmatización social y su muerte civil.

-Los beneficios para la sociedad: se reducen costes sociales y judiciales; se evita la concesión abusiva del crédito y se fomenta el crédito responsable; se fomenta el emprendimiento, la innovación y la actividad económica.

-Los beneficios para el acreedor: ahorro de costes judiciales frente a deudores insolventes; se le aporta un futuro cliente, directa o indirectamente, al incorporarse el deudor a la actividad económica.

Independientemente de que la aplicación efectiva de esta norma sea mayor o menor, o deba de ser modificada, lo fundamental es la introducción de la institución, pues, como indica VIGUER ${ }^{6}$, la Ley supone un paso muy importante, al matizar el principio de responsabilidad patrimonial universal del art. 1911 Cc.

\section{I.III. Marco legislativo europeo.}

\section{I.III.I. Antecedentes.}

Los antecedentes de más remotos en la Resolución del Parlamento Europeo a la Comisión de 17 de octubre de 2011; la posterior Comunicación de la Comisión de 12 de diciembre de 2012; la Recomendación de 12 de Marzo de 2014, del Parlamento Europeo a la Comisión, en materia de reestructuración y segunda oportunidad, y sus dos evaluaciones de aplicación en 2015 y 2016, que cuajaron en la Propuesta de Directiva del Parlamento Europeo y del Consejo de 22 de noviembre de 2016, sobre marcos de reestructuración preventiva, segunda oportunidad y medidas para aumentar la eficacia de los procedimientos de condonación, insolvencia y reestructuración, y de modificación de la Directiva 2012/30/UE sobre

\footnotetext{
${ }^{4}$ CUENA CASAS, M. "La insolvencia de la persona física: prevención y solución», en El Notario del Siglo XXI, mayo-junio 2015, $n^{\circ}$ 61. Madrid 2015, p. 478.

${ }^{5}$ BATLLORI, M. «La segunda oportunidad: un mecanismo eficaz, simple y en auge», en la obra colectiva La segunda oportunidad de las personas físicas: su aplicación práctica, VVAA, Ed. Vlex, Barcelona 2018, pp. 18-25.

${ }^{6}$ VIGUER SOLER, P.L. "Análisis crítico del RDL 1/2015 sobre "segunda oportunidad»: expectativas, luces y sombras», en Diario La Ley, nº 8592, Secc. Doctrina. 29 de julio de 2015. Ed. La Ley. Madrid 2015, p.14
} 
Derecho de Sociedades. Ésta propuesta de Directiva dedica a la segunda oportunidad el Título III (arts. 19 a 23), determinándose su ámbito de aplicación en el art. 1.

\section{I.III.II.- La Directiva de 20 de junio de 2019 , sobre marcos de reestructuración preventiva, exoneración de deudas e inhabilitaciones.}

La Resolución legislativa del Parlamento Europeo de 28 de marzo de 2019, sobre la propuesta de Directiva de 22 de noviembre de 2016, ha cuajado en la aprobación por el Parlamento Europeo y el Consejo, de la Directiva de 20 de junio de 2019 -publicada en el DOUE de 26 de Junio de 2019- sobre marcos de reestructuración preventiva, exoneración de deudas e inhabilitaciones, y sobre medidas para aumentar la eficiencia de los procedimientos de reestructuración, insolvencia y exoneración de deudas, y por la que se modifica la Directiva (UE) 2017/1132 (Directiva sobre reestructuración e insolvencia), regula la segunda oportunidad en su título III, rubricado "Exoneración de deudas e inhabilitaciones", arts. 20 a 24, y manteniendo su ámbito de aplicación en el art. 1. Su plazo de transposición por los Estados miembros de la UE es de dos años (art. 34, -con excepciones), por lo que es muy posible que el marco regulatorio actual sufra modificaciones, en especial en cuanto al plazo del plan de pagos en supuestos de exoneración provisional (se reduciría de 5 a 3 años), coincidente con el plazo de inhabilitación-si el deudor es de buena fe- y más largos -o denegatorios- si el deudor es deshonesto o ejercite abusivamente su derecho. Se fomenta igualmente la acumulación de procedimientos que afecten a deudas personales y profesionales, para su tramitación coordinada, ante un mismo tribunal. La Directiva prevé una exoneración directa, sin necesidad ni de plan de pagos ni de Acuerdo extrajudicial de pagos previo; admite igualmente una exoneración sin liquidación del patrimonio del deudor, y también una exoneración y liquidación con plan de pagos, pero sin imponer umbral mínimo de pasivo extinguido. Aunque la norma no opta por ninguno de los modelos como preferente, sino que deja la elección a la normativa nacional.

En cualquier caso, es una propuesta referida al deudor profesional, pero el Considerando (21) de la Directiva se dedica al sobreendeudamiento de los consumidores, recomendando a los Estados miembros que apliquen también a los consumidores, en el plazo más breve posible, las disposiciones de la Directiva en materia de exoneración de dudas. Entre la doctrina, CUENA CASAS ${ }^{7}$ ha criticado la exclusión de los consumidores, cuando es una política pública en muchos estados miembros; máxime, cuando la Directiva, aplicada a los empresarios, no distingue entre el pasivo empresarial y el doméstico.

\section{La solicitud del BEPI. Tratamiento procesal.}

El art. 178 bis LC, titulado "Beneficio de la exoneración del pasivo insatisfecho" regula todo el procedimiento aplicable, aunque contiene las necesarias remisiones para facilitar su encaje en la LC, tanto a la fase de liquidación y conclusión

${ }^{7}$ CUENA CASAS, M. «Hacia un nuevo régimen de segunda oportunidad para el empresario insolvente. (A propósito de la Directiva de 20 de junio de 2019 sobre marcos de reestructuración preventiva y exoneración de deudas). Blog “hayderecho. com", 7 de julio de 2019, p. 2 
(art. 152.3 LC) y calificación del concurso (art. 165.1.1 $\left.1^{\circ} \mathrm{LC}\right)$, como a las normas del Acuerdo Extrajudicial de Pagos (art. 231 LC) -en adelante, AEP- y las relativas al deber de colaboración e información al Juez del concurso y a Administración concursal (art. 42 LC).

Este artículo dispone que el deudor persona natural podrá obtener el beneficio de la exoneración del pasivo insatisfecho en los términos establecidos en este artículo, una vez concluido el concurso por liquidación o por insuficiencia de la masa activa.

Es decir, en principio, únicamente tras la finalización del concurso por liquidación, o por insuficiencia de los bienes para atender a todas las deudas reconocidas en el concurso, el deudor tiene la facultad, que no la obligación, de interesar la exoneración de deudas mediante lo que la ley califica de beneficio de exoneración del pasivo insatisfecho. No se configura tampoco como un procedimiento de oficio.

-Solicitud.-Para ello (apartado 2 del art. 178 bis LC), el deudor deberá presentar su solicitud de exoneración del pasivo insatisfecho ante el juez del concurso dentro del plazo de audiencia que se le haya conferido de conformidad con lo establecido en el artículo 152.3. LC, y que hace referencia al plazo de audiencia a las partes para formular oposición a la conclusión del concurso y la rendición de cuentas, y que es de quince (15) días (art. 176.2 LC).

También deberá formularse la solicitud, en el caso de comunicación de insuficiencia de masa conforme al art. 176 bis LC, en el trámite de audiencia de quince (15) días (art. 176.3 LC) sobre el informe justificativo del Administrador concursal.

Como tiene declarado la SAP Barcelona, Secc. $15^{a}$, de 29 de junio de 2018 (Fundamento de Derecho Tercero), el art. 178 bis LC prevé dos posibi- lidades para pedir la exoneración:

$1^{\circ}$.- Cuando hayan concluido las operaciones de liquidación:

«...7. Por lo tanto, la primera posibilidad de solicitud del beneficio de exoneración exige que se hayan concluido las operaciones de liquidación. Una vez concluidas las operaciones de liquidación: la Administración concursal debe presentar un informe final justificativo de las operaciones realizadas en el que razonará inexcusablemente que no existen acciones viables de reintegración de la masa activa ni de responsabilidad de terceros pendientes de ser ejercitadas ni otros bienes o derechos del concursado (art. 152.2 L). En tal caso, previa audiencia de las partes, el juez del concurso debe acordar la conclusión del concurso, conforme a lo previsto en el art. 152.3 LC. Pues bien, el propio art. 178 bis 2 prevé que en ese mismo plazo de audiencia el concursado pueda pedir la exoneración del pasivo insatisfecho».

$2^{\circ}$.- Cuando se evidencie la insuficiencia de la masa activa para pagar los créditos contra la masa:

"...8. El segundo supuesto previsto en el art. 178 bis. 1 LC para la solicitud del beneficio de la exoneración de pasivo es el de la insuficiencia de la masa activa para pagar los créditos contra la masa. En este caso, el art. 176 bis LC regula dos situaciones: (i) cuando declarado el concurso consecutivo el administrador concursal compruebe la insuficiencia de la masa activa para satisfacer los créditos contra la masa, en cuyo caso deberá comunicarlo y proceder a la realización de los bienes, pagando los créditos contra la masa conforme a los dispuesto en el art. 176 bis. 2 LC lart. 176 bis. 3 LC), y (ii) cuando el juez declara aquella misma insuficiencia en el auto declarando el 
concurso, en cuyo supuesto, el deudor puede solicitar la exoneración después de la declaración y conclusión (art. 176 bis.4 LC)».

En el mismo sentido se pronuncia el AAP Valencia, Secc. 9a , de 16 de enero de 2019, revoca un auto de un Juzgado de Primera instancia que acordó la conclusión precipitada del concurso, por inaplicación del art. 176 bis 4 LC, al impedir el acceso al BEPI.

Surgen dificultades en los concursos sin masa, en los que, por concepto, no puede el deudor acogerse al art. 178 bis. $3.4^{\circ}$ LC por carecer de activo para satisfacer el umbral de pasivo mínimo, conforme precisa la SAP Murcia, Secc. $4^{a}$, de 12 de noviembre de 2015.

En relación a esta problemática, el Auto de la AP Madrid, Secc. 28a , de 1 de febrero de 2019, matiza que si bien no puede procederse al archivo inmediato y simultáneo a la declaración de concurso, y debe nombrarse administrador concursal para que liquide bienes y pague los créditos contra la masa y ulteriormente, pueda el deudor solicitar el BEPI, por así determinarlo el párrafo $2^{\circ}$ del art. 176 bis.4 LC, en concursos sin masa y con un endeudamiento activo, en el supuesto enjuiciado, debe confirmarse el auto que concluyó el concurso sin dar esa opción pues la concursada se aquietó a la conclusión, no cursando en tiempo y forma la petición de exoneración; ni tampoco impugnó el auto de conclusión, por lo que no puede, tras la firmeza del mismo, solicitar el beneficio de la exoneración, y "es imposible ya acordar el desarchivo del concurso y el nombramiento de administrador concursal para su tramitación, a fin de servir de soporte procesal que sostenga la resolución finalmente de exoneración de pasivo . Por ello, el recurso debe ser desestimado, siempre sin perjuicio de iniciar de nuevo trámites de expediente extrajudicial de pagos o solicitud de concurso, con el objeto final de que sea examina- da la posibilidad de aplicar aquel beneficio de exoneración de pasivo".

-Tramitación de la solicitud. Conforme al apartado 4 del art. 178 bis LC, de la solicitud del deudor se dará traslado por el Letrado de la Administración de Justicia a la Administración concursal y a los acreedores personados por un plazo de cinco días para que aleguen cuanto estimen oportuno en relación a la concesión del beneficio, contemplándose estas dos situaciones:

$1^{\text {a }}$ - Si la Administración concursal y los acreedores personados muestran su conformidad a la petición del deudor o no se oponen a la misma, el juez del concurso concederá, con carácter provisional, el beneficio de la exoneración del pasivo insatisfecho en la resolución, declarando la conclusión del concurso por fin de la fase de liquidación.

$2^{a}$ Si se da oposición, ésta solo podrá fundarse en la inobservancia de alguno o algunos de los requisitos del apartado 3 del art. 178 bis LC, y se le dará el trámite del incidente concursal. Y se determina además que no podrá dictarse auto de conclusión del concurso hasta que gane firmeza la resolución que recaiga en el incidente reconociendo o denegando el beneficio.

En cualquier caso, ha de dejarse claramente dicho que el beneficio no puede concederse sin más, en ausencia de oposición, sino que el Juzgado ha de motivar su decisión acerca de la concurrencia o no de los presupuestos para su concesión. Es decir, la concesión se encuentra condicionada por la concurrencia de los requisitos legales. Por ello, la concesión del BEPI implica realizar, por parte del Juez del concurso, un "control de legalidad" al respecto de los presupuestos para su concesión, "al estar en presencia de requisitos de carácter imperativo, no disponibles 
por la voluntad de las partes" (SJM n ${ }^{0} 1$ de Oviedo de 9 de mayo de 2018). En el mismo sentido, la SAP Murcia, Secc. $4^{a}$ de 10 de enero de 2019, que reitera el criterio ya sentado en su anterior de 8 de septiembre de 2016. Criterio finalmente acogido en la STS (Pleno Sala $1^{\text {a) }}$ núm. 381/2019, de 2 de julio, que exige el cumplimiento de los requisitos legales de la opción escogida

\section{Presupuestos. Exoneración definitiva y provisional}

\section{III.I.Presupuestos.}

\section{III.I.I. Deudor persona natural y de buena fe.}

Conforme se dispone en el apartado 1 del art. 178 bis LC el deudor persona natural podrá obtener el beneficio de la exoneración del pasivo insatisfecho en los términos establecidos en este artículo, una vez concluido el concurso por liquidación o por insuficiencia de la masa activa. Como ya hemos dicho, la persona natural puede ser o no empresario, por lo que el acceso a este beneficio es universal para las personas físicas.

El apartado 3 del art. 178 bis LC declara tajantemente que solo se admitirá la solicitud de exoneración del pasivo insatisfecho a los deudores de buena fe, que es aquel deudor en el que concurran una serie de requisitos previstos taxativamente en el referido apartado, en sus cinco apartados y que será objeto de estudio inmediato. Como sostienen CAMPUZANO/SANJUÁN ${ }^{8}$, la determi- nación de esta concurrencia no es una facultad discrecional del Juez, sino que es un "concepto jurídico normativo», pues constituye una presunción iuris tantum condicionada al cumplimiento de cinco requisitos, tres de ellos comunes (los tres primeros, $1^{\circ}$ a $\left.3^{\circ}\right)$ y dos alternativos $\left(4^{\circ} \mathrm{y}\right.$ $\left.5^{\circ}\right)$, que conforman dos modelos distintos de segunda oportunidad, la que conlleva la exoneración definitiva, y la provisional, por sometimiento a un plan de pagos. Esta calificación de concepto normativo y no valorativo es sustentada por PULGAR EZQUERRA 9 , a similitud del denominado "test de discharge» en el ordenamiento anglosajón, al tratarse de un contenido determinado legalmente, $y$ sin que en modo alguno se conecte la buena fe a las causas que provocaron la insolvencia.

La configuración legal del concepto de deudor de buena fe, propugnado desde la doctrina y determinado con claridad en la nueva norma, es un requisito crucial, y que despeja los miedos hacia el oportunismo, las insolvencias estratégicas y las especulaciones sobre el efecto llamada. SANJUÁN ${ }^{10}$ identifica el referido concepto con el de "deudor honesto", más propio de la terminología comunitaria; o el de "deudor honrado pero desafortunado", muy propio de la terminología estadounidense, y adoptado entre la doctrina nacional por SENDRA ALBIÑANA ${ }^{11}$.

La STS (Pleno Sala $1^{\text {a }) ~ n u ́ m . ~ 381 / 2019, ~ d e ~}$ 2 de julio, viene a confirmar esta tesis normativa, al declarar que la referencia legal a que el deudor sea de buena fe no se vincula al concepto general del art. 7.1 Cc, sino al cumplimiento de los requisitos enumerados en el apartado 3 del art. 178

\footnotetext{
${ }^{8}$ CAMPUZANO LAGUILlo,A.B/SANJUÁN Y MUÑOZ,E. GPS Concursal, Ed. Tirant lo Blanch, Valencia 2019, p. 745, con cita de la SJM nº 1 de Murcia de 10 de marzo de 2016.

${ }^{9}$ PULGAR EZQUERRA, J. Preconcursalidad y reestructuración empresarial. Ed. La Ley-Wolters Kluwer, 2a Edición, Madrid 2016, p.920.
} 
LC, cuya naturaleza es heterogénea. Reitera el Tribunal Supremo que la denuncia de la inexistencia de buena fe exigida por el art. 178 bis 3 LC se debe ceñir al cumplimiento de estos requisitos y no, como se postula por el recurrente, a que en la solicitud inicial se hubiera omitido la existencia de un crédito contra la masa que luego, al oponerse la AEAT, fue admitida.

A continuación comentaremos los cinco requisitos, tres (3) comunes y dos (2) alternativos, según los dos modelos de exoneración, provisional y definitiva.

\section{III.I.II.- Concurso no declarado culpable y excepción legal.}

1. ${ }^{\circ}$ Que el concurso no haya sido declarado culpable. No obstante, si el concurso hubiera sido declarado culpable por aplicación del artículo 165.1.1. ${ }^{\circ}$ LC, el juez podrá no obstante conceder el beneficio atendidas las circunstancias y siempre que no se apreciare dolo o culpa grave del deudor.

Se trata del primer requisito común a ambos tipos de exoneración. Se exige la tramitación de la pieza de calificación en todo concurso de persona física ${ }^{12}$, y permite su excepción si no se aprecia ni dolo ni culpa grave, en el supuesto de que el concurso haya sido calificado culpable por la concurrencia de la presunción iuris tantum de incumplimiento del deber de solicitar la declaración de concurso establecida en el art. 165.1.1 ${ }^{\circ}$ LC. En cualquier caso, la calificación del concurso como fortuito constituye una presunción de concurrencia del referido requisito, salvo prueba en contrario.

Ahora bien, en la práctica como recuerda PUIGCERVER ${ }^{13}$, con cita de la SAP Barcelona, Secc. 15a , de 29 de junio de 2018, en los concursos con insuficiencia de masa nos encontramos con la imposibilidad de declarar sobre la culpabilidad del concurso, "si en el auto de declaración y archivo se argumentó que no había responsabilidad de terceros, y si el mediador al solicitar el concurso no solicitó la apertura de la fase de liquidación, no puede el Juez concursal al tiempo de resolver sobre la solicitud de exoneración del pasivo analizar si el concurso es o no culpable, cuando nada se ha alegado ni se ha tramitado la fase concursal correspondiente".

La excepción legal, a mi juicio, supone una contradicción conceptual con la calificación cul-

10 SANJUÁN Y MUÑOZ, E. "El concepto de buena fe en supuestos de segunda oportunidad», en la obra colectiva dirigida por SÁNCHEZ RUIZ DE VALDIVIA, I/OLMEDO CARDENETE, M, Presente y futuro del Mercado Hipotecario y Ley de Segunda Oportunidad para consumidores/as y empresarios/as, ED. Thomson Reuters Aranzadi, Cizur Menor, Navarra, 2015, p. 798 y ss.

11 SENDRA ALBIÑANA, A. El beneficio de exoneración del pasivo insatisfecho, ed. Tirant lo Blanch, Valencia 2018, p. 71.

12 No obstante, si el concurso hubiera sido declarado culpable por aplicación del artículo $165.1 .1 .^{\circ}$ LC, que hace referencia al supuesto de haber incumplido el deber de solicitar la declaración del concurso, el juez podrá no obstante conceder el beneficio atendidas las circunstancias y siempre que no se apreciare dolo o culpa grave del deudor.

13 PUIGCERVER ASOR, C. "El beneficio de exoneración del pasivo insatisfecho», en la obra colectiva La aplicación práctica de la segunda oportunidad: problemas y respuestas. PUIGCERVER ASOR,C/ADAN DOMÉNECH, F. Ed. Librería Bosch, Barcelona 2019, p. 124. 
pable que determina la cláusula general del art. 164.1 LC, por la apreciación de esa conducta dolosa o gravemente culposa, ya que la jurisprudencia (SSTS de 1 de abril y 3 de julio de 2014, y 1 de junio de 2015) ha declarado que las presunciones iuris tantum -entre las que se encuentra la excepcionable del art. $165.1 .1^{\circ}$ LC según el art. 178 bis $3.1^{\circ}$, inciso segundo-, contienen una concreción de lo que puede constituir una conducta gravemente culpable con incidencia causal en la generación o agravación de la insolvencia, y será muy difícil justificar sólo "atendidas las circunstancias" después de la declaración de culpabilidad por el motivo excepcionable, que no se dio, al menos, culpa grave.

\section{III.I.III. Inexistencia de condena penal del concursado.}

Este es el segundo de los requisitos comunes a los dos modelos de exoneración, regulado en el número $2 .^{\circ}$ del art. 178 bis 3 :

"Que el deudor no haya sido condenado en sentencia firme por delitos contra el patrimonio, contra el orden socioeconómico, de falsedad documental, contra la Hacienda Pública y la Seguridad Social o contra los derechos de los trabajadores en los 10 años anteriores a la declaración de concurso. Si existiera un proceso penal pendiente, el juez del concurso deberá suspender su decisión respecto a la exoneración del pasivo hasta que exista sentencia penal firme".

Estamos ante una concepción absolutamente objetiva, que impide cualquier margen de apreciación judicial, y que atiende a un posible ámbito penal tanto del deudor persona física empresario como no empresario, al contemplar delitos propios del ámbito empresarial, de posible comisión únicamente por empresarios; y delitos socioeconómicos de posible comisión por los particulares.

En la práctica, se exige la aportación de un certificado de antecedentes penales junto con la solicitud, y ello se exige no únicamente para entender la comisión de los hechos, sino para calcular el propio plazo de 10 años. Se recomienda la atenta lectura de la SAP Asturias, Secc. $1^{a}$, de 17 de enero de 2019, en relación a los antecitados tipos penales y el plazo de cancelación de antecedentes.

Muchos problemas da en la práctica la suspensión de la tramitación hasta la firmeza de la causa penal, que se erige como absolutamente indisponible por el Juez del concurso, aunque entre la doctrina $^{14}$ haya voces que propugnan continuar con la tramitación y valorar la sentencia en sede de revocación del beneficio. Postura que no comparto.

\section{III.I.IV.- Intento y/o celebración de un acuerdo extrajudicial de pagos (AEP)}

El tercero de los requisitos comunes a los dos tipos de exoneración es el regulado en el número 3. "Que, reuniendo los requisitos establecidos en el artículo 231, haya celebrado o, al menos, intentado celebrar un acuerdo extrajudicial de pagos".

Este requisito, para CUENA CASAS $^{15}$ debe estar referido únicamente al deudor que pueda hacerlo por reunir los requisitos del art.231 LC;

\footnotetext{
${ }^{14}$ PUIGCERVER ASOR, C, op. cit., pp. 127 y 128.

${ }^{15}$ CUENA CASAS, M, op. cit., p. 484.
} 
como sabemos, los requisitos exigidos en el referido precepto no son otros que no superar un pasivo de cinco millones de euros, y no concurran en su persona los requisitos negativos de los apartados 3 y 4 para los propios acuerdos extrajudiciales de pagos $^{16}$. Opinión que comparto totalmente, y que ratifica el Auto de la AP de Valencia, Secc. $9^{a}$, de 11 de febrero de $2019^{17}$.

La citada autora ${ }^{18}$ precisa que la exoneración de las deudas debe solicitarla el deudor tras la conclusión del concurso por liquidación del activo o por insuficiencia de masa (art. 178 bis.1.LC); y dado que el deudor debe intentar un AEP, lo normal es que la exoneración se plantee en el marco del concurso consecutivo (arts. 242 y 242 bis LC); aunque, como precisa esta misma autora, este requisito del intento de AEP se excepciona en el art. 178 bis.3.4 $4^{\text {L }}$ LC, por lo que cualquier deudor puede no intentar un acuerdo extrajudicial y beneficiarse del régimen del inciso $1^{\circ}$ del art. 178 bis. $3.4^{\circ}$ siempre que logre abonar las deudas no exonerables -que serán los créditos contra la masa, y los créditos concursales privilegiados- $y$, además el $25 \%$ del importe de los créditos concursales ordinarios.

Esta opinión es aceptada mayoritariamente por la doctrina y por la jurisprudencia posterior. En tal sentido, la SAP Pontevedra, Secc. $1^{\text {a }}$, de 25 de enero de 2016, entendiéndose que el requisito de formulación del AEP es condición indispensable para optar al beneficio de la exoneración por todos aquellos deudores que cumplan los requisitos de acceso al AEP establecidos en el art. 231 LC; de tal forma que, quien satisface el $25 \%$ del crédito ordinario por no haberse sometido al AEP, lo hace porque no se encuentra legitimado para solicitar el AEP, como sintetiza SENDRA ALBIÑA$N A^{19}$ o por simplemente, por no haberlo hecho encontrándose posibilitado legalmente para ello. La SAP Barcelona, Secc. 15a, de 13 de febrero de 2017 declara que "sólo en defecto de un acuerdo extrajudicial intentado, si hubiera sido posible legalmente hacerlo, debe exigirse al deudor el pago de una cuarta parte del pasivo ordinario". Criterio

${ }^{16}$ El apartado 3 del art. 234 LC establece que no podrán formular solicitud para alcanzar un acuerdo extrajudicial de pagos: $1^{\circ}$.Quienes hayan sido condenados en sentencia firme por delito contra el patrimonio, contra el orden socioeconómico, de falsedad documental, contra la Hacienda Pública, la Seguridad Social o contra los derechos de los trabajadores en los 10 años anteriores a la declaración de concurso. $2^{\circ}$.- Las personas que, dentro de los cinco últimos años, hubieran alcanzado un acuerdo extrajudicial de pagos con los acreedores, hubieran obtenido la homologación judicial de un acuerdo de refinanciación o hubieran sido declaradas en concurso de acreedores. El cómputo de dicho plazo comenzará a contar, respectivamente, desde la publicación en el Registro Público Concursal de la aceptación del acuerdo extrajudicial de pagos, de la resolución judicial que homologue el acuerdo de refinanciación o del auto que declare la conclusión del concurso. El art. 231.4 LC dispone que no podrán acceder al acuerdo extrajudicial de pagos quienes se encuentren negociando con sus acreedores un acuerdo de refinanciación o cuya solicitud de concurso hubiera sido admitida a trámite.

17 Este auto revoca el recurrido, que inadmite una solicitud de declaración de concurso voluntario de acreedores, y que archivó la solicitud por no haberse acreditado el previo intento de AEP.

18 CUENA CASAS, M. "La exoneración del pasivo insatisfecho", en la obra colectiva coordinada por PRATS ALBENTOSA, L. Comentarios a la Ley de Mecanismo de Segunda Oportunidad. Ed Thomson Reuters Aranzadi, Cizur Menor, Navarra, 2016, p, 88 y p. 100

19 SENDRA ALBIÑANA, A. op cit., pp. 160 y 161. En el mismo sentido, FERNÁNDEZ GONZÁLEZ, V.M; BLANCO GARCíA-LOMAS, L; DÍAZ REVORIO, E., en El concurso de acreedores de la persona física. Con especial atención a la mediación concursal y a la Ley de Segunda Oportunidad Ed. La Ley, Wolters-Kluwer, Madrid 2016, p. 370. 
reiterado por la SAP Barcelona, Secc. 15 ${ }^{\mathrm{a}}$, de 9 de abril de 2019, en sintonía ya con la STS de 13 de marzo de 2019 (Ponente Sancho Gargallo), en la que se declara Fundamento de Derecho Segundo, apartado 5, que:

"El requisito del ordinal $3^{\circ}$ se refiere a que se hubiera instado el expediente de acuerdo extrajudicial de pagos, que al verse frustrado, dio paso al concurso consecutivo, a cuya conclusión por insuficiencia de activo el deudor interesa el beneficio de la exoneración del pasivo insatisfecho. De modo que, a los efectos del ordinal $3^{\circ}$, basta con la materialidad de que se hubiera instado y tramitado el expediente de acuerdo extrajudicial de pagos.

Mientras que la referencia contenida en el ordinal $4^{\circ}$ de que se hubiera intentado el acuerdo extrajudicial de pagos para que no sea necesario el previo pago del $25 \%$ del pasivo concursal ordinario, se refiere a que hubiera habido un intento efectivo de acuerdo. Esto es, que hubiera habido una propuesta real a los acreedores, al margen de que no fuera aceptada por ellos. Esta referencia pretende incentivar la aceptación por los acreedores de acuerdos extrajudiciales de pagos, a la vista de que en caso contrario el deudor podría obtener la remisión total de sus deudas con el pago de los créditos contra la masa y privilegiados. Pero para esto es necesario que, en la propuesta de acuerdo extrajudicial de pagos, a los acreedores ordinarios se les hubiera ofrecido algo más que la condonación total de sus créditos. En la ratio del ordinal $4 .^{\circ}$ subyace esta idea del incentivo negativo a los acreedores ordinarios para alcanzar el acuerdo extrajudicial de pagos propuesto por el deudor, pues si no lo aceptan, en el concurso consecutivo pueden ver extinguidos totalmente sus créditos.

Si, como ocurre en el presente caso, en la práctica no se ofrece nada, pues la propuesta era la extinción o quita del $100 \%$ de los créditos, hemos de concluir, como hizo la Audiencia, que no se había intentado un acuerdo extrajudicial de pagos. Por esta razón, el Sr. Hipólito no podía obtener el beneficio de la exoneración del pasivo insatisfecho por la alternativa del ordinal $4 .^{\circ}$ del art. 178 bis 3 LC , sin que previamente hubiera acreditado haber pagado el $25 \%$ del importe de los créditos concursales ordinarios".

Muy acertadamente, PULGAR EZQUERRA 20 sostuvo que, en la práctica, "la persona física que acude a un AEP lo hace básicamente con una finalidad instrumental, como vía para obtener en un eventual concurso consecutivo la exoneración del pasivo insatisfecho ex. art. 178 bis LC" y no a través de un concurso no consecutivo, en una razón básica: en que "el "perímetro de exoneración material» resulta más amplio en el marco de un concurso consecutivo si previamente se ha alcanzado un acuerdo extrajudicial de pagos, aunque haya sido sin éxito, como medio para propiciar el recurso a la mediación preconcursal". Afirmación que claramente se justifica en los dos distintos alcances de los sistemas alternativos de exoneración -definitiva y provisional- previstos, respectivamente, en los números $4^{\circ}$ y $5^{\circ}$ del art. 178 bis 3 LC, como veremos a continuación.

Igualmente, no pueden cumplir este requisito aquéllos concursos iniciados con anterioridad a la propia existencia del AEP, introducido por la Ley 14/2013, de 27 de septiembre de 2013, y con vigencia desde el 18 de octubre de 2013. Habrá de

20 PULGAR EZQUERRA, J. Preconcursalidad y reestructuración empresarial. Ed. La Ley-Wolters Kluwer, $2^{\text {a }}$ Edición, Madrid 2016, p. 893-894. 
estarse también a lo dispuesto en la disposición transitoria primera de la Ley 25/2015, de 28 de julio; situación interpretada por la jurisprudencia en cuanto a la inaplicabilidad a concurso anteriores a la entrada en vigor de las normas citadas ( $v$. gr. el AJM n. ${ }^{\circ} 1$ de Barcelona de 2 de marzo de 2016; AJM n. ${ }^{\circ} 6$ de Madrid, de 28 de marzo de 2017; requisito que es obligatorio para los Autos de la AP Pontevedra, Sección primera, de 25 de enero de 2016; y AP Murcia, Sección 4a , de 12 de noviembre de 2015).

No obstante, se pronuncian en contra de esa interpretación, sin necesidad de exigir ese pago suplementario del $25 \%$ de los créditos concursales ordinarios, en supuestos de inexistencia de regulación del AEP al tiempo de declararse el concurso, postulando la posibilidad de acogerse a la exoneración definitiva para los concursados anteriores a la entrada en vigor de la Ley 14/2013 y RD-Ley 1/2015 (que introdujeron los AEP para empresarios y no empresarios, respectivamente), el AAP Girona, Secc. $1^{a}$, de 5 de marzo de 2018 y SJM 2 de Palma de Mallorca, de 15 de marzo de 2018.

La jurisprudencia postula una interpretación amplia y flexible del citado requisito de intentar el AEP; el AAP de Lleida, Secc. $2^{\mathrm{a}}$, de 11 de febrero de 2019 recuerda que debe ser considerado cualquier supuesto en el que se ponga fin al procedimiento de AEP; doctrina que ha sido acogida por los Juzgados y Tribunales y en tal sentido SAP Barcelona, sec., 15, de 26 de mayo de 2017 ; SAP Baleares de 10 de noviembre de 2017 y S. del Juzgado de lo Mercantil n 7 , Barcelona, S 0311-2016. Dicho todo lo anterior, y dada su consi- deración de requisito esencial SAP Sevilla, Secc. $5^{\mathrm{a}}$, de 6 de noviembre de 2017), de ese esfuerzo razonable intento razonable (SAP Barcelona, Secc. 15a , de 31 de enero de 2019), es aconsejable razonar acerca de cuándo puede tenerse por intentado el AEP.

A este respecto, PUIGCERVER ${ }^{21}$ sistematiza muy acertadamente estas situaciones de intento y celebración del AEP, en la siguiente forma, entendiendo que:

a) Se considera intentado el AEP en situaciones de falta de conformidad del cónyuge (art. 232.2 LC); por falta de aceptación del mediador (art. 249.2 LC, SAP Barcelona, Secc. 15a , de 31 de enero de 2019); y por impedimento penal sobrevenido.

b) Se considera no intentado el AEP cuando se dé inadmisión de la solicitud por incumplimiento de los presupuestos del art. 231 LC, ex art. 232.3 LC, cuando se solicite el AEP por una sola parte del pasivo, y no por la totalidad de créditos (SJPI $n^{\circ} 2$ de Segovia de 9 de mayo de 2018); y, en general, cuando concurra una inexistencia de negociaciones serias.

En la práctica, en materia de concurso de persona física no empresaria, surgen muchos problemas en cuanto a la falta de aceptación del mediador y al tratamiento de la cuestión por los Notarios competentes territorialmente para el conocimiento del concurso (art. 242 bis.1.1 ${ }^{\circ}$ LC). La Resolución de la Dirección General de los Registros y del Notariado de 14 de mayo de 2019, resuelve una consulta interpretativa formulada en 19 de noviembre de 2018 por la Junta Directiva del Iltre. Colegio Notarial de Madrid, en la que, tras analizar la problemática, doctrinal y jurispru-

21 PUIGCERVER ASOR, C., op cit., pp. 132 a 138. 
dencial $^{22}$, y las soluciones adoptadas al respecto en la práctica notarial, y su interpretación judicial, y concluir la ausencia normativa en el art. 233 LC, en relación a las consecuencias de la falta de aceptación del mediador en el expediente notarial -más allá de lo dispuesto en el art. 19.3 del RD 980/2013, de 13 de diciembre, de postergación del mediador al final de la lista secuencial de nombramientos-, concluye que si transcurre el plazo de dos meses a contar desde el primer intento de designación de mediador concursal, sin que se produzca la aceptación de ninguno de los mediadores, el Notario podrá cerrar el expediente, debiendo hacer constar en la diligencia de cierre que el mismo se produce por la imposibilidad de alcanzar un Acuerdo extrajudicial de pagos por falta de aceptación de los mediadores concursales sucesivamente designados durante el plazo de dos meses a que se refiere el art. 242 bis.1, apartados $8^{\circ}$ y $9^{\circ} \mathrm{LC}$, facilitándosele copia al deudor requirente a fin de que pueda instar, en su caso, el concurso consecutivo ante el juzgado competente.

Esta solución, que, en principio, puede ser aceptada, al no perjudicar al deudor, choca, a nuestro entender, no obstante, con la posibilidad de que sea el propio Notario el que actúe como mediador concursal (242.bis $3^{\circ}$ LC), y así salve la falta de aceptación de los sucesivos designados como mediadores, cuya designación es, a tenor de la referida norma, facultativa.

\section{III.II.- El pago de un umbral de pasivo y la exoneración definitiva.}

La exoneración definitiva de deudas -sin sujeción a plan de pagos ni espera temporal ningunase regula en el número $4^{\circ}$ del art. 178 bis 3 LC, y se configura como uno de los dos medios para acceder a esa segunda oportunidad, exigiendo del deudor que haya satisfecho en su integridad los créditos contra la masa ${ }^{23}$ y los créditos concursales privilegiados ${ }^{24} ; y$, si no hubiera intentado un acuerdo extrajudicial de pagos previo, al menos, hubiera satisfecho el 25 por ciento del importe de los créditos concursales ordinarios ${ }^{25}$.

Hemos de precisar aquí que la deuda insatisfecha o el pasivo pendiente de pago tras la eje-

22 La RDGRN de 14 de mayo de 2019 se hace eco de las distintas opciones prácticas, y su distinto reflejo en la jurisprudencia. Así, se hace referencia al criterio de la RDGRN de 5 de febrero de 2018, sobre la designación de mediadores concursales conforme al sistema secuencial, que es contraria a la designación directa ante la falta de aceptación, o ante el cierre del expediente tras un número determinado de designaciones fallidas. La resolución igualmente se hace eco del criterio jurisprudencial contrario a la inadmisión del concurso consecutivo cuando no se de aceptación del mediador (AAP de Tarragona de 8 de noviembre de 2018, auto 231/2018; y AAP Barcelona de 27 de diciembre de 2018, núm. 188/2018, y 31 de enero de 2019, núm. 12/2019; y SAP Valladolid, de 17 de enero de 2019, núm. 14/2019, que consideran que, ante el silencio legal, y la falta de responsabilidad del deudor, debe entenderse por intentado el acuerdo extrajudicial de pago, a pesar de la falta de aceptación del mediador, aunque éste precise de su intervención, al tratarse de una cuestión ajena al deudor.

${ }^{23}$ Art. 84 LC

${ }^{24}$ Arts. 89 a 91 LC.

${ }^{25}$ Art. 89.3 LC, los que no son ni privilegiados ni subordinados. Hay que tener en cuenta el régimen transitorio de la Disposición transitoria primera, apartado 4, en el que no será exigible, para obtener el beneficio de la exoneración del art. 178 bis LC, el requisito del apartado $3.5^{\circ}$.iv) durante el año siguiente a la entrada en vigor de la Ley 25/2015. 
cución hipotecaria sería considerado crédito ordinario; en tal sentido, SÁNCHEZ JORDÁN ${ }^{26}$, que lo deduce del juego de los artículos 89.3, 90.3 y 94.5, todos de la LC. Posición que compartimos.

Esta situación de pago de los créditos no exonerables determinada en el art. 178 bis. $3.4^{\circ} \mathrm{LC}$ determina la previa liquidación del patrimonio del concursado no únicamente hasta la satisfacción de aquéllos, sino que se exige la liquidación del patrimonio restante tras ese pago, pues el BEPI es un beneficio para aquéllos deudores que no pueden afrontar más extinción de deuda. En tal sentido se pronuncia la SAP Barcelona, secc. $15^{a}$, de 21 de septiembre de 2016, en relación a la liquidación pendiente de los derechos consolidados de un plan de pensiones. Personalmente entiendo que debe flexibilizarse esta exigencia, atendida la naturaleza de los bienes y de la posibilidad/imposibilidad de su venta.

En cualquier caso, la exoneración del art. 178 bis.3.4 $4^{\circ}$ LC es una exoneración definitiva de los créditos pendientes, que serán, en cualquier caso, créditos ordinarios y subordinados. Igualmente, podrán tratarse igualmente de créditos por alimentos y los créditos públicos, siempre que no tengan la consideración de créditos contra la masa.

\section{III.III. La sujeción a un plan de pagos y la exoneración provisional.}

El número $5^{\circ}$ del apartado 3 del art. 178 bis LC determina un camino alternativo a la exoneración definitiva, que pasa por la aceptación de un plan de pagos, la postergación de éstos, al verse su pago diferido en el tiempo, máximo de cinco (5) años, y el previo cumplimiento de una serie de requisitos legales que a continuación se indican.

Se trata de una opción distinta a la contemplada en el apartado 4, la exoneración definitiva, y que se prevé legalmente "a modo de plan B", si se permite la coloquial expresión, ya que establece que, alternativamente al número anterior, es decir, al apartado o requisito $4^{\circ}$ del art. 178 bis 3 LC. Por ello, como precisa CUENA CASAS ${ }^{27}$, tal y como está redactado el art. 178 bis $3.4^{a}$ y $5^{a}$, LC, el deudor puede optar por el abono de umbral de pasivo mínimo o acogerse a un plan de pagos en el caso de que tal umbral no pueda satisfacerse.

HERNÁNDEZ RODRÍGUEZ ${ }^{28}$ rechaza la tesis que pudiera deducir del tenor de la norma que considera que no constituye requisito de acceso a la exoneración del pasivo insatisfecho, sino de manera exclusiva para la determinación del monto del pasivo que ha de haber sido atendido por el deudor, al entender que el legislador ha pretendido que todo deudor legitimado para ello intenten un acuerdo extrajudicial de pagos de manera previa a acudir a la vía concursal, potenciando con ello la solución alternativa al concurso; todo ello sin perjuicio de que al fijar el mínimo del pasivo que ha de ser atendido por el deudor, que se acoge a la primera alternativa del precepto, esto es, el del apartado $3.4^{\circ}$, diferencia entre aquel deudor que intentó un previo acuerdo extrajudicial de pagos y el que no lo hizo por carecer de legitimación para ello, careciendo de sentido introducir el

\footnotetext{
${ }^{26}$ SÁNCHEZ JORDÁN, El régimen de segunda oportunidad...op cit., p. 127-131.

${ }^{27}$ CUENA CASAS, M. "La exoneración del pasivo insatisfecho", en la obra colectiva coordinada por PRATS ALBENTOSA, L. Comentarios a la Ley de Mecanismo de Segunda Oportunidad. Ed Thomson Reuters Aranzadi, Cizur Menor, Navarra, 2016, p.105. ${ }^{28}$ HERNÁNDEZ RODRÍGUEZ, Ma M. La segunda oportunidad. La superación de las crisis de inso/vencia. Ed. Lefevre/El Derecho, $2^{\mathrm{a}}$ ed., Madrid 2015, pp.95-96.
} 
ordinal $3.4^{\circ}$ en otro caso.

Personalmente entiendo que la redacción del ordinal $5^{\circ}$ no necesita interpretación posible; se interpreta claramente que ofrece una alternativa, otra posibilidad al apartado $4^{\circ}$, pues establece una variante o alternativa a éste, dado que dice -como ya decía el RD-Ley 1/2015-, "50 Que alternativamente al número anterior". Consecuentemente, el exigir el haber intentado el AEP carece de sentido cuando la propia norma ofrece una alternativa, que se materializa con la introducción del "plan de pagos" y los requisitos que le son propios. Propugnar la obligatoriedad de acudir al AEP corre el riesgo de que lo convierta en una mera formalidad, que erosione su utilidad, y que pueda minar la credibilidad en la intención sincera de la propuesta de AEP en aquel deudor que opte por esa vía. Carece de sentido proponer ese requisito como exigencia pues habrá deudores que no podrán acogerse al AEP por superar su pasivo la cifra de $5 \mathrm{~mm}$ de euros exigidos por el art. 231 LC, o al menos intentarlo, aun a sabiendas de no estar incluido en el supuesto de hecho de la norma. Además, ambas opciones distinguen claramente dos vías para la obtención del beneficio de la exoneración: la primera, que exige la satisfacción de un cierto nivel de pasivo, con carácter de mínimo en la liquidación concursal; y una segunda, que no exige haber satisfecho ese mínimo, pero sí el someterse a un plan de pagos durante cinco años.

Éste es el criterio de SENENT MARTÍNEZ/ GALLEGO SÁNCHEZ/NIETO DELGADO/VILLENA CORTÉS ${ }^{29}$, quienes entienden que a pesar de que la regulación de los AEP ha mejorado notablemente, y se permite el acceso de cualquier deudor, y su contenido se asemeja al previsto para el convenio concursal o el acuerdo de refinanciación, el exigir necesariamente el haber intentado un AEP para poder obtener el beneficio de la liberación de deudas se antoja un requisito excesivo. Además, esa exigencia no es absoluta, sino que si no se logra el AEP, aún es posible obtener el beneficio de la liberación de deudas si se cumplen todos los requisitos del apartado $5^{\circ}$ del núm. 3 del art. 178 bis. También sigue esta interpretación entre la doctrina, JIMÉNEZ PARÍS ${ }^{30}$. Y ha sido el criterio del la STS (Pleno Sala $1^{\mathrm{a}}$ ) núm. 381/2019, de 2 de julio, en su Fundamento de Derecho Cuarto

Así, el art. 178 bis. $3.5^{\circ}$ LC establece que, alternativamente al número anterior, el $4^{\circ}$, el deudor verá exonerada provisionalmente la deuda no extinguida con la liquidación concursal, si cumple las siguientes exigencias, y que pasan por que:

i) Acepte someterse al plan de pagos previsto en el apartado 6.

ii) No haya incumplido las obligaciones de colaboración establecidas en el artículo 42.

iii) No haya obtenido este beneficio dentro de los diez últimos años.

iv) No haya rechazado dentro de los cuatro años anteriores a la declaración de concurso una oferta de empleo adecuada a su capacidad.

v) Acepte de forma expresa, en la solicitud de exoneración del pasivo insatisfecho, que la obtención de este beneficio se hará constar en la sección especial del Registro Público Concursal por un plazo de cinco años.

\footnotetext{
29 Op. cit., p. 13

30 JIMÉNEZ PARÍS, T.A. «El régimen de segunda oportunidad introducido por el Real Decreto-Ley 1/2015, de 27 de febrero. Revista Crítica de Derecho Inmobiliario, n 750/2015. Madrid 2015, p.2371 a 2373.
} 
Únicamente tendrán acceso a esta sección las personas que tengan interés legítimo en averiguar la situación del deudor, entendiéndose en todo caso que tienen interés quienes realicen una oferta en firme al deudor ya sea de crédito o de cualquier otra entrega de bienes o prestación de servicios, que tenga que ser remunerada o devuelta por éste y que esté condicionada a su solvencia, así como las Administraciones Públicas y órganos jurisdiccionales habilitados legalmente para recabar la información necesaria para el ejercicio de sus funciones. La apreciación de dicho interés se realizará por quién esté a cargo del Registro Público Concursal.

-En relación con estas exigencias, ha de decirse que, en la práctica, surgen problemas en cuanto al rechazo de ofertas de empleo adecuadas a la capacidad, pues admite un amplio margen de interpretación, en relación a personas carentes de formación reglada, o de experiencia profesional dilatada.

-Sobre la aceptación de someterse a un plan de pagos, la SAP Murcia, Secc. $4^{a}$, de 10 de enero de 2019, recuerda que

"es controvertido si para la solicitud de exoneración basta con manifestar la aceptación a someterse al plan de pagos (SAP de Barcelona, de 29 de junio de 2018), o debe ser éste presentado, lo que parece lógico es que se resuelva judicialmente sobre su aprobación o modificación al tiempo de pronunciarse sobre el reconocimiento o denegación del beneficio. Así concluye, tras un detallado análisis, la SAP de Valencia, Secc. 9a, de 16 de octubre de 2018: "(la) proposición del plan concreto, su contradicción y aprobación debe ser posterior a la solicitud de exoneración, pero anterior a la sentencia que resuelva la exoneración lesta tramitación coetánea se deduce también de la Sentencia de AP Baleares, Sección 5a) de 21 de septiembre de 2016; Audiencia Provincial de Madrid, sección 28a, en Sentencia de 2 de enero de 2018. Si la sentencia debe evaluar la buena fe del solicitante sobre la base de su aceptación de un concreto plan de liquidación, ese concreto plan debe estar aprobado y aceptado con anterioridad al dictado de la sentencia en el incidente que resuelva la solicitud de exoneración. Ello no exige necesariamente que el plan se proponga con la solicitud (aunque sería lo deseable), pero sí durante la tramitación del expediente».

-Conforme se dispone en el apartado 6 del art. 178 bis LC, el beneficio de la exoneración del pasivo insatisfecho concedido a los deudores previstos en el número $5 .^{\circ}$ del apartado 3 se extenderá a la parte insatisfecha de los siguientes créditos:

1. ${ }^{\circ}$ Los créditos ordinarios y subordinados pendientes a la fecha de conclusión del concurso, aunque no hubieran sido comunicados, y exceptuando los créditos de derecho público y por alimentos.

2. ${ }^{\circ}$ Respecto a los créditos enumerados en el artículo 90.1 LC (créditos privilegiados garantizados con prenda o hipoteca, voluntaria o legal), la parte de los mismos que no haya podido satisfacerse con la ejecución de la garantía quedará exonerada salvo que quedara incluida, según su naturaleza, en alguna categoría distinta a la de crédito ordinario o subordinado.

Según al apartado 6 del art. 178 bis LC, las deudas que no queden exoneradas conforme a lo dispuesto en el apartado 5 anterior, deberán ser satisfechas por el concursado dentro de los cinco años siguientes a la conclusión del concurso, salvo que tuvieran un vencimiento posterior. 
Durante los cinco años siguientes a la conclusión del concurso las deudas pendientes no podrán devengar interés.

Es decir, no pueden exonerarse provisionalmente más que los créditos anteriormente referidos, y deberán abonarse durante los cinco años siguientes a la aprobación del plan de pagos, pues forman parte del mismo, los créditos siguientes:

$1^{\circ}$.- Los créditos contra la masa y los créditos privilegiados (SAP Madrid, Secc. 28 ${ }^{\mathrm{a}}$, de 2 de enero de 2018).

$2^{\circ}$.- La parte de los créditos con privilegio especial no satisfechos con la ejecución de la garantía, si no es calificado como crédito ordinario o subordinado.

$3^{\circ}$.- Los créditos de derecho público, con independencia de su naturaleza ordinaria, subordinada o contra la masa (SAP Barcelona, Secc. 15a , de 29 de junio de 2016, y STS núm. 387/2019, de 2 de julio).

$4^{\circ}$.- Los derivados de la obligación de alimentos, con independencia de su calificación como ordinario o crédito contra la masa (SAP Barcelona, Secc. 15a, de 2 de junio de 2017).

Aprobada la exoneración provisional, los acreedores cuyos créditos se extingan no podrán iniciar ningún tipo de acción dirigida frente al deudor para el cobro de los mismos (art. 178 bis. 6 in fine LC).

-El plan de pagos. A tal efecto, el deudor deberá presentar una propuesta de plan de pagos que, oídas las partes por plazo de 10 días, será aprobado por el juez en los términos en que hubiera sido presentado o con las modificaciones que estime oportunas.

En cuanto a la configuración legal del plan de pagos, FERNÁNDEZ GONZÁLEZ/BLANCO GARCÍA-LOMAS/DÍAZ REVORIO ${ }^{31}$, se muestran críticos al respecto de la escueta e imprecisa regulación del mismo en el apartado 6 del art. 178 bis LC, pues sobre el mismo únicamente se exige como requisito el fijar un calendario de abono de los créditos respecto de los que no cabe exoneración, y que se plazo máximo sea de cinco años, sin mayores formalidades o exigencias de contenido; a diferencia del convenio concursal, que cuenta con una regulación más detallada.

Entiendo que, en cualquier caso, siempre será un documento de buenas intenciones, por lo que se explica que el legislador no haya exigido ninguna exigencia mayor, ni formal ni en cuanto a la viabilidad de lo propuesto. En cualquier caso, la SAP Murcia, Secc. $4^{\mathrm{a}}$, de 10 de enero de 2019, y SAP Barcelona, secc. $15^{a}$, de 14 de noviembre de 2018, declaran no puede pretenderse resolver sobre la viabilidad del plan de pagos en el incidente de oposición a la exoneración provisional si el mismo no ha sido impugnado expresamente por esos motivos.

No considera la SAP Madrid, Secc. $28^{\mathrm{a}}$, de 1 de febrero de 2019, que sea posible equiparar a un plan de pagos la simple propuesta de entrega de un vehículo en pago a la financiera, en los siguientes términos:

\footnotetext{
${ }^{31}$ FERNÁNDEZ GONZÁLEZ, V. /BLANCO GARCÍA-LOMAS, L./DÍAZ REVORIO, E. El concurso de acreedores de la persona física. Con especial atención a la mediación concursal y a la Ley de Segunda Oportunidad. Ed. La Ley Wolters Kluver, Madrid 2016, pp. 371 y ss.
} 
"Porque lo que hizo fue limitarse a mencionar en el texto de su escrito que su propuesta de plan de pagos era, simplemente, proceder a la entrega del vehículo a la financiera ly no señalar un calendario sobre la cadencia temporal de los pagos a efectuar a ésta). Pero eso no constituye plan de pago alguno, sino una propuesta de convenio o acuerdo para la extinción de un crédito privilegiado, cuando una solución de ese tipo sólo podría ser admisible en otra clase de escenario concursal (el convenio, el acuerdo extrajudicial, etc), que aquí no cabría reproducir. El plan de pagos no existía en este caso, no sólo porque materialmente el concursado no se molestó en elaborarlo como tal, sino porque la mera alusión que al mismo se efectuó en el seno de su escrito no estaba dotada del contenido suficiente para permitir equipararlo a tal."

Igualmente, la SAP Valladolid, Secc. $3^{\mathrm{a}}$, de 17 de enero de 2019, rechaza un plan de pagos que "carece de un mínimo calendario de pagos, con fraccionamiento y fijación de plazos para atender el total del pasivo no exonerable. Además, más allá de las cuestiones formales, consideramos que la inclusión en la propuesta del plan de los elementos a valorar por el juez para el caso de incumplimiento del plan a los efectos de la exoneración definitiva, supone una perversión del sistema tal y como fue concebido por el legislador, pues aboca, irremediablemente, a un ficticio cumplimiento del mal denominado plan de pagos, privando con ello al juez de la posibilidad de valorar las circunstancias concurrentes". En cualquier caso, estimo muy acertado el criterio de la Secc. $1^{\text {a }}$ de la AP de Córdoba, que en Auto de 10 de enero de 2019, estima que, para salvaguardar el derecho constitucional a la tutela judicial efectiva, debe de concederse posibilidad de subsanación del documento o incluso, su propia aportación.

Este criterio es el que finalmente ha acogido el Tribunal Supremo en la Sentencia de 2 de julio de 2019, núm. 381/2019, que incluso admite su presentación -y la opción por la exoneración provisional del $n^{\circ} 5$, pese a una inicial opción por la definitiva del $n^{\circ} 4^{\circ}$, ambos del apartado 3 del art. 178 bis LC- incluso en el escrito de contestación a la demanda incidental formulada por el acreedor público frente a la solicitud (Fundamento de Derecho Tercero, 2), ya que, a decir de la referida resolución, el art. 178 bis LC no establece un procedimiento rígido para solicitar y obtener la exoneración del pasivo, que presuponga la imposibilidad de variar la opción inicial por una de las dos alternativas legales, la del ordinal $4^{\circ}$ o la del $5^{\circ}$, siempre y cuando se cumplan las garantías legales que permitan la contradicción sobre el cumplimiento de los requisitos propios de la alternativa del ordinal finalmente escogido.

Ha de recordarse que, en los cinco años siguientes a la remisión provisional de sus deudas sometidas al plan de pagos, el deudor acudirá a solicitar la remisión definitiva de las mismas (apartado 7 del art. 178 bis LC). Quizás, lo más negativo de esta disposición sea el largo plazo de declaración provisional del beneficio de cinco años, que es superior en dos años al sugerido en la normativa comunitaria. Entiendo, no obstante, que el plazo de cinco años en un plazo de máximos, pudiendo establecerse en el plan de pagos un plazo inferior.

Transcurrido el plazo fijado para el cumplimiento del plan de pagos sin que se haya revocado el beneficio, el juez del concurso, a petición del deudor concursado, dictará auto reconociendo con carácter definitivo la exoneración del pasivo insatisfecho en el concurso (art. 178 bis.8 LC), que 
es irrecurrible, pero que, como veremos, puede revocarse.

-Incumplimiento del plan de pagos y exoneración definitiva: la "nueva segunda oportunidad".

Se regula así lo que, entre la doctrina, PUL$G A R^{32}$ denomina como "la nueva segunda oportunidad", y SENDRA ${ }^{33}$ como "la excepción de incumplimiento del plan de pagos"; y que, como veremos, tiene su repercusión igualmente en sede de revocación del beneficio de la exoneración concedida provisionalmente, en el que actúa como una excepción a una de las causas.

Dispone el art. 178 bis.8 LC que el Juez del concurso también podrá, atendiendo a las circunstancias del caso y previa audiencia de los acreedores, declarar la exoneración definitiva del pasivo insatisfecho del deudor que no hubiese cumplido en su integridad el plan de pagos pero que:

$1^{\circ}$.- Hubiese destinado a su cumplimiento, al menos, la mitad de los ingresos percibidos durante el plazo de cinco años desde la concesión provisional del beneficio que no tuviesen la consideración de inembargables o

$2^{a}$.- Hubiese destinado la cuarta parte de dichos ingresos cuando concurriesen en el deudor las circunstancias previstas en el artículo 3.1, letras a) y b), del Real Decreto-ley 6/2012, de 9 de marzo, de medidas urgentes de protección de deudores hipotecarios sin recursos, respecto a los ingresos de la unidad familiar y circunstancias familiares de especial vulnerabilidad.
A los efectos de este artículo, se entiende por ingresos inembargables los previstos en el artículo 1 del Real Decreto-ley 8/2011, de 1 de julio, de medidas de apoyo a los deudores hipotecarios, de control del gasto público y cancelación de deudas con empresas y autónomos contraídas por las entidades locales, de fomento de la actividad empresarial e impulso de la rehabilitación y de simplificación administrativa.

Se establece legalmente la facultad judicial de conceder la exoneración definitiva al deudor que, incumplidor del plan de pagos -y por tanto, incurso en causa de revocación del beneficio ex art. 178 bis 7 LC, segundo párrafo, letra b)- ha comprometido un esfuerzo económico en intentar incumplir el plan de pagos, atendiendo a las circunstancias y previa audiencia de los acreedores. Los problemas regulatorios son muchos, ya que no se establece ningún pago mínimo en relación al pasivo exonerado para apreciar esa excepción; ni tampoco, si es vinculante el plazo propuesto en el plan de pagos inferior, que sea inferior a cinco años, a estos efectos, en supuesto de no alcanzar el pago de ese $25 \%$ de los ingresos; o puede "prorrogarse" hasta los cinco máximos legales en espera de completar el pago exigido por la Ley, despreciando la limitación del plan de pagos propuesto inicialmente.

\section{III.IV. Efectos del BEPI sobre el cónyuge y los fiadores del concursado.}

-Efectos sobre el cónyuge del concursado.- Si el concursado tuviere un régimen económico matrimonial de gananciales $u$ otro de comunidad y no se hubiere procedido a la liquidación de dicho

\footnotetext{
32 PULGAR EZQUERRA, J., Op cit., p. 937.

33 SENDRA ALBIÑNANA, A, Op cit., p. 254.
} 
régimen, el beneficio de la exoneración del pasivo insatisfecho se extenderá al cónyuge del concursado, aunque no hubiera sido declarado su propio concurso, respecto de las deudas anteriores a la declaración de concurso de las que debiera responder el patrimonio común.

Ha de precisarse que el perímetro de exoneración lo es sobre deudas anteriores a la declaración de concurso de que deban responder los bienes gananciales, con independencia de la declaración en concurso del cónyuge in bonis.

-Efectos sobre los fiadores.- Quedan a salvo los derechos de los acreedores frente a los obligados solidariamente con el concursado y frente a sus fiadores o avalistas, quienes no podrán invocar el beneficio de exoneración del pasivo insatisfecho obtenido por el concursado ni subrogarse por el pago posterior a la liquidación en los derechos que el acreedor tuviese contra aquél, salvo que se revocase la exoneración concedida.

Se prohíben las acciones de regreso de los fiadores que paguen la deuda en virtud de las obligaciones derivadas de la fianza, pero se preserva el interés de los acreedores afianzados, a los que nada afecta la exoneración del pasivo.

\section{III.V.- La problemática de la inclusión del crédito público en el plan de pagos (STS 2 de julio de 2019).}

Dispone el último párrafo del apartado 6 del art. 178 bis LC, que

“Respecto a los créditos de derecho público, la tramitación de las solicitudes de aplazamiento o fraccionamiento se regirá por lo dispuesto en su normativa específica".
La jurisprudencia estima que el crédito público ha de ser incluido en el plan de pagos, en virtud de la exclusividad de su aprobación por parte del Juez del concurso, y derivado de la necesidad de que toda la deuda se encuentre incluida dentro del plan; sin perjuicio de la normativa específica en cuanto al aplazamiento o fraccionamiento, y la simultaneidad de uno y otro. Es ejemplo de esta doctrina jurisprudencial la SAP Barcelona, Secc. $15^{a}$, de 29 de junio de 2018, en cuyo Fundamento Jurídico Séptimo establece lo siguiente:

"21.- La discusión se centra en la inclusión del crédito público en el plan de pagos, única deuda no exonerable que estaba pendiente de pago en el caso que nos ocupa. Respecto del mismo, no hay discusión que la solicitud de aplazamiento o fraccionamiento se tramitarán al margen del concurso con arreglo a la normativa específica (art. 178 bis. 6 in fine LC), como expresamente se reconoce por el deudor y se solicitó, tal y como consta en autos, pero ello no impide que el crédito público deba incluirse en el plan de pagos, junto con el resto de deudas no exonerables que por imperativo legal deben de pagar en todo caso para obtener el beneficio de exoneración lart. 178 bis.5 y 6 LC).

22.- La exposición de motivos del RDL 1/2015, de 27 de febrero, por el que se introduce la regulación del art. 178 bis $L C$, no hace ninguna distinción cuando refiere a las deudas no exonerables que deberán satisfacerse en el plazo de cinco años conforme al plan de pagos cuando indica "alternativamente, cuando no hayan podido satisfacer los anteriores créditos y siempre que acepte someterse a un plan de pagos durante los 5 años siguientes, el deudor podrá quedar exonerado provisionalmente de todos sus créditos, excepto los públicos y por alimentos, contra la masa y aquéllos que 
gocen de privilegio general. Para la liberación definitiva de deudas, el deudor deberá satisfacer en ese período las deudas no exoneradas o realizar un esfuerzo sustancial para ello."

23.- Por ello, en el plan de pagos deben incluirse todas las deudas que no queden exoneradas, también los créditos de derecho público, pues de lo contrario difícilmente se podrá valorar la conveniencia de un plan de pagos que no incluya todas las deudas a satisfacer. La interpretación contraria nos llevaría a la paradoja que habiéndose concedido en sede concursal el beneficio de exoneración y aprobado un plan de pagos, su cumplimiento final se hiciera depender de que la Administración Tributaria concediera o no el aplazamiento interesado, lo que carece de toda lógica.

24. - Ahora bien, una vez aprobado el plan de pagos, deberá tramitarse el aplazamiento o fraccionamiento de los créditos públicos que se incorporen a la propuesta de plan de pagos, siempre que se ajuste a lo dispuesto en el párrafo primero del apartado 6 ("deberán ser satisfechas por el concursado dentro de los cinco años siguientes a la conclusión del concurso, salvo que tuvieran un vencimiento posterior. Durante los cinco años siguientes a la conclusión del concurso las deudas pendientes no podrán devengar interés").

25.- Por ello, como en el caso que nos ocupa, la solicitud del beneficio o de la aprobación del plan de pagos puede ser simultánea a la solicitud de aplazamiento ante la AEAT, cuando en aquél se incluyan créditos públicos, teniendo en cuenta que la concesión administrativa del citado fraccionamiento será siempre posterior a la aprobación del plan de pagos y al archivo del concurso por imposición de la propia normativa administrativa, de conformidad con el art. 65.2 Ley General Tributaria , que impide la concesión cuando el obligado tri- butario esté en concurso (Instrucción 1/2017, de 18 de enero de la Directora del Departamento de Recaudación de la Agencia Estatal de Administración Tributaria, sobre gestión de aplazamientos y fraccionamientos de pago).

26. - Por consiguiente, concluimos que el aplazamiento y fraccionamiento de los créditos tributarios forma parte del plan de pagos previsto en el art. 178 bis.6 LC, y deberá ajustarse a los criterios establecidos en el mismo, pero cabe su tramitación y resolución ante la Administración tributaria con carácter posterior a su incorporación al plan de pagos.

27.- Teniendo en cuenta lo expuesto, debemos estimar el recurso de apelación en el sentido de conceder el beneficio de exoneración solicitado por el deudor al reunir los requisitos del art. 178 bis. 3 LC así como aprobar el plan de pagos presentado con inclusión del crédito público en el mismo, sin perjuicio de la posterior tramitación de la solicitud de aplazamiento o fraccionamiento con arreglo a la normativa específica.

En el mismo sentido, reitera doctrina la SAP Barcelona, secc. 15a , de 11 de febrero de 2019.

La STS (Pleno Sala 1ª), núm. 381/2019, de 2 de julio, ha venido a zanjar esta polémica, al declarar en su Fundamento de Derecho Cuarto, apartado 5, que "Aprobado judicialmente un plan de pagos, no es posible dejar su eficacia a una posterior ratificación de uno de los acreedores, en este caso el acreedor público. Aquéllos mecanismos administrativos para la condonación y aplazamiento de pago carecen de sentido en una situación concursal. Esta contradicción hace prácticamente ineficaz la consecución de la finalidad perseguida por el art. 178 bis LC lque pueda alcanzarse en algún caso la exoneración plena de la deuda), por lo que, bajo una interpretación teleo- 
lógica, ha de subsumirse la protección perseguida del crédito público en la aprobación judicial. El juez, previamente, debe oír a las partes personadas (también al acreedor público) sobre las objeciones que presenta el plan de pagos, y atender sólo a aquellas razones objetivas que justifiquen la desaprobación del plan".

La referida STS de 2 de julio de 2019 alcanza esta conclusión, rechazando cualquier posicionamiento que imposibilite que el plan de pagos pueda acordar aplazamientos o fraccionamientos del crédito público, bajo la perspectiva de la exoneración plena de la deuda, interpretando los ordinales $4^{\circ}$ y $5^{\circ}$ del apartado 3 del art. 178 bis con el apartado 5 del art. 178 bis, referido a los créditos afectados por la exoneración del pasivo insatisfecho, entendiendo que la exoneración plena debe alcanzar a todos los créditos ajenos al plan de pagos -créditos contra la masa y privilegiados- razonando la exoneración plena a partir de la Exposición de Motivos del RDL 1/2015, de 27 de febrero, que introdujo el art. 178 bis LC, así como los postulados de la Recomendación de la Comisión Europea de 12 de abril de 2016, y a la Directiva (UE) 2019/1023, del Parlamento Europeo y del Consejo, sobre marcos de reestructuración preventiva y exoneración de deudas, pero no

"para extraer de ellas una norma jurídica, sino para constatar cuál es la finalidad perseguida por la institución y los principios que deberían tomarse en consideración para realizar una interpretación teleológica del art. 178 bis LC. La finalidad de la norma es facilitar la segunda oportunidad, mediante la condonación plena de las deudas. Esta condonación puede ser inmediata o en cinco años. En ambos casos se supedita a unas exigen- cias que justifiquen la condición de buena fe del deudor y a un reembolso parcial de la deuda. Este reembolso parcial debe tener en cuenta el interés equitativo de los acreedores $y$, en la medida de lo posible, debería ser proporcionado a los activos y la renta embargables o disponibles del deudor concursado, pues de otro modo en la mayoría de los casos la exoneración del pasivo se tornaría imposible, y la previsión normativa devendría prácticamente inaplicable. En atención a estas consideraciones, entendemos que, en principio, la exoneración plena en cinco años (alternativa del ordinal 5. ${ }^{\circ}$ ) está supeditada, como en el caso de la exoneración inmediata lalternativa del ordinal 4. \%, al pago de los créditos contra la masa y con privilegio general, aunque en este caso mediante un plan de pagos que permite un fraccionamiento y aplazamiento a lo largo de cinco años. Sin perjuicio de que en aquellos casos en que se advirtiera imposible el cumplimiento de este reembolso parcial, el juez podría reducirlo para acomodarlo de forma parcial a lo que objetivamente podría satisfacer el deudor durante ese plazo legal de cinco años, en atención a los activos y la renta embargable o disponible del deudor, y siempre respetando el interés equitativo de estos acreedores (contra la masa y con privilegio general), en atención a las normas concursales de preferencia entre ellos.

Con esta interpretación no se posterga tanto el crédito público, pues con arreglo a lo previsto en el art. 91.4. ${ }^{\circ}$ LC, el 50\%, descontado el que tenga otra preferencia o esté subordinado, tiene la consideración de privilegiado general, y por lo tanto quedaría al margen de la exoneración".

La trascendencia de este pronunciamiento no ha dejado de sorprender ni ha dejado a nadie indiferente. Entre la doctrina, CUENA CASAS ${ }^{34}$ se ha

\footnotetext{
${ }^{34}$ CUENA CASAS, M. «Segunda oportunidad y crédito público (A propósito de la mal entendida Sentencia del Tribunal Supremo de 2 de julio de 2019). Publicación en el blog hayderecho.com, 29 de julio de 2019, p. 2 a 4
} 
mostrado muy crítica al respecto de esta interpretación, ya que no se da, a su juicio, ninguna duda interpretativa del art. 178 bis 5 LC, que es claro, entendiendo que la interpretación que realiza el Tribunal Supremo se extralimita en su resolución de 2 de julio de 2019, ya que determina los créditos afectados por la exoneración, en forma que vulnera la Ley; afirma la citada autora que, si bien es cierto que la LC establece que el pasivo exonerable del deudor que se acoge al plan de pagos es distinto y más exigente que aquél que se acoge al abono inmediato del umbral del pasivo mínimo, no hay jurisprudencia que lo cuestione; y que podrá compartirse o no, pero no hay manera de saltarse el art. 178 bis 5 LC, nos guste o no, al establecer, expresamente, que los deudores que se acogen al plan de pagos no pueden exonerarse del crédito público. Para la citada autora, el TS equipara el régimen de los dos tipos de deudores en cuanto al pasivo exonerable, y ese resultado no puede conseguirse vía interpretación; concluyendo la referida autora que "...No se puede convertir un deseo en criterio de interpretación. A mí también me gustaría decir que el régimen de deudas exonerables es único para todo deudor, pero no lo es"; y termina con un argumento de refuerzo a su tesis: "El problema es qué dirá el TS cuando la esposalo divorciada/o de un deudor concursado reclame pensiones por alimentos debidas y no pagadas. La LC permite la exoneración de las deudas por alimentos al deudor que se acoge al art. 178 bis. $3.4^{\circ}$ LC y se lo prohíbe de manera expresa al deudor que se acoge al plan de pagos (art. 178. bis 5 LC)", formulando una pregunta retórica, muy dura: “¿Qué le dirá el TS a la esposa/o cuando el progenitor deudor se acoge al plan de pagos? ¿También le traerá a colación la Exposición de Motivos de la LC, la Recomendación europea o la Directiva europea todavía no transpuesta? Tengo auténtica curiosidad...".

Contrariamente, para SANJUÁN Y MUNOOZ ${ }^{35}$ la STS de 2 de julio de 2019 "supone un antes y un después en la posibilidad de exoneración de deuda para los deudores honestos en concurso de acreedores, incluida la pública", y le merece una buena opinión, ante lo restrictivo del régimen administrativo, perjudicial para la segunda oportunidad, aunque prevé un cambio legislativo que rectifique las consecuencias que a efectos recaudatorios tiene la referida doctrina jurisprudencial.

\section{La revocación del BEPI. Trata- miento procesal.}

La revocación del BEPI se contempla en el apartado 7 del art. 178 bis LC, tanto para la concesión definitiva, como la para concesión provisional, en forma diferenciada, y en los siguientes términos:

$1^{\circ}$.- Revocación aplicable a los dos tipos de concesión del BEPI, provisional y definitiva. Cualquier acreedor concursal estará legitimado para solicitar del juez del concurso la revocación del beneficio de exoneración del pasivo insatisfecho cuando durante los cinco años siguientes a su concesión se constatase la existencia de ingresos, bienes o derechos del deudor ocultados. Se exceptúan de esta previsión los bienes inembargables conforme a lo dispuesto en los artículos 605 y 606 de la Ley 1/2000, de 7 de enero, de Enjuiciamiento Civil.

\footnotetext{
${ }^{35}$ SANJUÁN Y MUÑOZ, E. "Exoneración de deuda a la luz de la Sentencia del TS de 2 de julio de 2019». Workpaper (4) julio 2019, p.9.
} 
Se establece aquí una causa de revocación genérica o común para las dos formas de exoneración -definitiva o provisional, y que se identifica con una conducta de ocultación de bienes, y que justifica la revocación del beneficio por razones propias de justicia material hacia los acreedores, aun con la excepción de inembargabilidad establecida.

CAMPUZANO/SANJUÁN ${ }^{36}$ distinguen entre una revocación impropia, que sería la aplicable exclusivamente a la exoneración concedida con carácter provisional; y una revocación propia, que procedería cuando concurre la causa de mejora de fortuna o de ocultación de un activo prevista en el párrafo primero, pero aplicable a los dos tipos de exoneración.

$2^{\circ}$.- Revocación específica de la exoneración provisional. También podrá solicitarse la revocación si durante el plazo fijado para el cumplimiento del plan de pagos:

a) Incurriese en alguna de las circunstancias que conforme a lo establecido en el apartado 3 hubiera impedido la concesión del beneficio de la exoneración del pasivo insatisfecho.

b) En su caso, incumpliese la obligación de pago de las deudas no exoneradas conforme a lo dispuesto en el plan de pagos, 0 .

c) Mejorase sustancialmente la situación económica del deudor por causa de herencia, legado o donación; o juego de suerte, envite o azar, de manera que pudiera pagar todas las deudas pendientes sin detrimento de sus obligaciones de alimentos.
En cuanto a las causas provisionales, se plantean dudas en cuanto a su aplicación, ya que, como es sabido, hay motivos de concesión en el apartado 3 de difícil incumplimiento, ya que vienen referidos a situaciones ya consolidadas antes de concederse, como la calificación del concurso. Por ello, el supuesto paradigmático y casi único en la práctica, será el de la comisión de un delito.

Además, en cuanto al incumplimiento del plan de pagos, vemos que se regula una excepción de incumplimiento, antes comentada, en el art. 178 bis 8 LC.

Por último, tampoco se define claramente la mejora "sustancial" de la situación económica, por lo que el margen de apreciación sigue siendo amplio, aunque siempre condicionado al pago de las deudas pendientes, sin perjuicio de las deudas por alimentos.

-Tratamiento procesal. Legitimados para instar la revocación se encuentran los acreedores, únicos afectados por la exoneración.

La solicitud de revocación del BEPI se tramitará conforme a lo establecido en la Ley de Enjuiciamiento Civil para el juicio verbal. En caso de que el juez acuerde la revocación del beneficio, los acreedores recuperan la plenitud de sus acciones frente al deudor para hacer efectivos los créditos no satisfechos a la conclusión del concurso.

Entiendo que la introducción de las normas reguladoras del Juicio verbal supone una distorsión en el proceso concursal, ya que, recordemos, se establece con carácter general el trámite del incidente concur-

\footnotetext{
${ }^{36}$ CAMPUZANO LAGUILLO,A/SANJUÁN Y MUÑOZ, E, Op cit., pp. 755.
} 
sal en el art. 192 LC para todas aquéllas cuestiones que se susciten durante el concurso y no tengan señalado un específico trámite concursal. Y además, se establece una completa regulación de este incidente -arts. 193 a 196 LC, con lo que entiendo criticable esta excepción. Todo ello, por pura coherencia, aunque soy consciente de la coincidencia de muchos trámites, no existe identidad absoluta, en materia de admisión de prueba y de celebración de vista, que no es vinculante en el incidente, aun que sea interesada por las partes.

Surgen igualmente dudas en cuanto al plazo de ejercicio de la acción; la pretensión de revocación de la exoneración definitiva entiendo que se somete al plazo de cinco años desde la concesión, que será de caducidad. Y en cuanto a la revocación de la provisional, habrá de estarse al plazo determinado en el plan de pagos, igualmente, de caducidad.

Ha de recordarse aquí la irrecurribilidad de la resolución de concesión de la exoneración definitiva del BEPI (art. 178 bis 8 in fine LC), con publicación de la resolución en el Registro Público concursal, pero también, como decimos, la posibilidad de la revocación de la concesión de la exoneración definitiva.

\section{Derecho transitorio.}

El RD-Ley 1/2015, de 27 de febrero, $y$ posterior Ley 25/2015, de 28 de julio, de mecanismo de segunda oportunidad, reducción de la carga financiera y otras medidas del orden social, establecieron en su Disposición transitoria primera, el siguiente régimen de derecho transitorio:

En su número 3, se dispuso que los apartados 3 y 4 del artículo 176 bis y los artículos 178.2 y 178 bis de la Ley Concursal se aplicarían a los concursos que se encontraran en tramitación, por lo que la aplicación del BEPI se impuso desde la entrada en vigor de las dos normas. Y en los concursos concluidos por liquidación o por insuficiencia de masa activa antes de la entrada en vigor de la presente Ley, el deudor podría beneficiarse de lo establecido en los artículos 176 bis y 178 bis de la Ley Concursal, si se instase de nuevo el concurso, voluntario o necesario.

En su número 4, se estableció que durante el año siguiente a la entrada en vigor de la Ley, no sería exigible, para obtener el beneficio de la exoneración previsto en el artículo 178 bis de la Ley Concursal, el requisito previsto en el apartado 3.5. ${ }^{\circ}$.iv) del mismo, cual era el referente al rechazo de la oferta de empleo adecuada a su capacidad. 


\section{Bibliografia.}

BATLLORI, M. «La segunda oportunidad: un mecanismo eficaz, simple y en auge», en la obra colectiva La segunda oportunidad de las personas físicas: su aplicación práctica, VVAA, Ed. Vlex, Barcelona 2018

CAMPUZANO LAGUILLO,A.B/SANJUÁNY MUÑOZ,E. GPS Concursal, Ed. Tirant lo Blanch, Valencia 2019.

CUENA CASAS, M. "La exoneración del pasivo insatisfecho", en la obra colectiva coordinada por PRATS ALBENTOSA, L. Comentarios a la Ley de Mecanismo de Segunda Oportunidad. Ed Thomson Reuters Aranzadi, Cizur Menor, Navarra, 2016.

-«La insolvencia de la persona física: prevención y solución», en El Notario de/ Siglo XXI, mayo-junio 2015, n 61 . Madrid 2015

-«Hacia un nuevo régimen de segunda oportunidad para el empresario insolvente. (A propósito de la Directiva de 20 de junio de 2019 sobre marcos de reestructuración preventiva y exoneración de deudas). Blog "hayderecho.com", 7 de julio de 2019.

-«Segunda oportunidad y crédito público. (A propósito de la mal entendida Sentencia del Tribunal Supremo de 2 de julio de 2019). Blog hayderecho.com, 29 de julio de 2019.

FERNÁNDEZ GONZÁLEZ, V. /BLANCO GARCÍA-LOMAS, L./DÍAZ REVORIO, E. El concurso de acreedores de la persona física. Con especial atención a la mediación concursal y a la Ley de Segunda Oportunidad. Ed. La Ley Wolters Kluver, Madrid 2016.

GUTIÉRREZ DE CABIEDES, P. «La Liberación de la deuda restante tras la liquidación en el sobreendeudamiento de los particulares", en la obra colectiva dirigida por PULGAR EZQUERRA, J./PACCHI,S. El sobreendeudamiento de los particulares y del consumidor. Sistemas jurídicos europeos a debate. Ed. Euriconv., Lecce, Italia, 2014.

HERNÁNDEZ RODRíGUEZ, Ma M. La segunda oportunidad. La superación de las crisis de insolvencia. Ed. Lefevre/El Derecho, $2^{\mathrm{a}}$ ed., Madrid 2015.

JIMÉNEZ PARÍS, T.A. «El régimen de segunda oportunidad introducido por el Real Decreto-Ley 1/2015, de 27 de febrero. Revista Crítica de Derecho Inmobiliario, nº 750/2015. Madrid 2015.

PUIGCERVER ASOR, C. "El beneficio de exoneración del pasivo insatisfecho», en la obra colectiva La aplicación práctica de la segunda oportunidad: problemas y respuestas. PUIGCERVER ASOR,C/ADAN DOMÉNECH, F. Ed. Librería Bosch, Barcelona 2019.

PULGAR EZQUERRA, J. Preconcursalidad y reestructuración empresarial. Ed. La Ley-Wolters Kluwer, 2ª Edición, Madrid 2016. SANJUÁN Y MUÑOZ, E. "El concepto de buena fe en supuestos de segunda oportunidad», en la obra colectiva dirigida por SÁNCHEZ RUIZ DE VALDIVIA, I/OLMEDO CARDENETE, M, Presente y futuro del Mercado Hipotecario y Ley de Segunda Oportunidad para consumidores/as y empresarios/as, ED. Thomson Reuters Aranzadi, Cizur Menor, Navarra, 2015.

-«Exoneración de deuda a la luz de la Sentencia del TS de 2 de julio de 2019». Workpaper (4) julio 2019.

SENDRA ALBIÑANA, A. El beneficio de exoneración del pasivo insatisfecho, ed. Tirant lo Blanch, Valencia 2018.

SENENT MARTíNEZ, S.; GALLEGO SÁNCHEZ, A.M; NIETO DELGADO, C.; VILLENA CORTÉS, F.B.; «Real Decreto-Ley 1/2015, de 27 de febrero, de mecanismo de segunda oportunidad, reducción de carga financiera y otras medidas de orden social». Fascículo de actualización de la Ley Concursal Comentada, Ed. Francis Lefevre/El Derecho, Madrid 2015.

VIGUER SOLER, P.L. "Análisis crítico del RDL 1/2015 sobre "segunda oportunidad»: expectativas, luces y sombras», en Diario La Ley, nº 8592, Secc. Doctrina. 29 de julio de 2015. Ed. La Ley. Madrid 2015. 
